

\title{
Correlation of nutritional element levels in drinking water with body compositions of women aged 55-70 years living in Batman province
}

\author{
İhsan Çetin', Mahmut Tahir Nalbantcilar'2, Ramazan İnci'3 ${ }^{3}$ Meryem Saban Güler'1, \\ Kezban Tosun ${ }^{4}$, Aydan Nazik ${ }^{4}$
}

1 Batman University, School of Health, Nutrition and Dietetics Department, Batman, Turkey

2 Batman University, Engineering and Architecture Faculty, Geology Engineering Department, Batman, Turkey

3 Batman University, School of Health, Nursery Department, Batman, Turkey

4 Batman Regional State Hospital, Dietetics Polyclinic, Batman, Turkey

Received :10.12.2016; Revised: 23.01.2017; Accepted:02.02.2017

\begin{abstract}
Objective: A growing interest in cellular targets of nutritional minerals and biochemical mechanisms has attracted the attentions of researchers towards their role in formation of obesity. However, there is no study investigating the effects of nutritional drinking water element levels on body composition of the elderly. Therefore, we aimed to examine the effects of nutritional element levels in drinking water on body compositions of women aged 55-70.

Methods: This research covers a population of 80 individuals as subjects in total, and was divided into three groups as overweight, obese and control women aged between 55-70. The bioelectric impedance device was used for the measurements of body composition of the participants. Measured values of cobalt (Co), copper $(\mathrm{Cu}), \mathrm{Iron}(\mathrm{Fe})$, manganese (Mn), selenium (Se) and zinc ( $\mathrm{Zn}$ ) levels of drinking water were measured via plasma mass spectrometry coupled inductively.

Results: It was found that Se mineral content in drinking water was correlated with the individuals' body mass index of participants living in Batman, Turkey. Moreover, it was found that $\mathrm{Fe}, \mathrm{Cu}, \mathrm{Co}, \mathrm{Zn}, \mathrm{Mn}$ and Se levels of drinking water were significantly correlated with the abdominal adiposity of women of 55-70.

Conclusion: It may be suggested that the obesity risk may be higher in women who are between 55-70 and consume drinking water with high levels of $\mathrm{Fe}, \mathrm{Cu}, \mathrm{Co}, \mathrm{Zn}, \mathrm{Mn}$ and especially Se.
\end{abstract}

Keywords: Drinking water, nutritional elements, obesity in elderly, body mass index, abdominal adiposity

DOI: $10.5798 /$ dicletip.298617

Yazışma Adresi/Correspondence: Ihsan Cetin, Batman University, School of Health, Nutrition and Dietetics Department, Batman, Turkey, e-mail: cetinihsan@gmail.com 


\section{İçme suyu besinsel element düzeylerinin Batman ilinde yaşayan 55-70 arası kadınlara ait vücut kompozisyonlarıyla korelasyonu}

Özet

Amaç: Besinsel minerallerin hücresel hedefleri ve biyokimyasal mekanizmaları hakkında artan ilgi, araştırmacıları besinsel elementlerin obezitenin oluşumundaki rollerine yönelik araştırmalara yönlendirmiştir. Ancak, yaşlı bireylerde vücut kompozisyonu üzerine içme suyu besinsel elementler düzeylerinin etkilerini araştıran bir çalışma yoktur. Bu nedenle, çalışmamızda 55-70 yaş arası kadınların vücut kompozisyonu üzerine içme suyu besinsel element düzeylerinin etkisinin incelenmesi amaçlanmıştır.

Yöntemler: Çalıșmaya 55-70 yaş arası, fazla kilolu, obez ve kontrol olarak üç gruba ayrılan toplam 80 katılımcı dâhil edilmiştir. Kadınlara ait vücut kompozisyonu ölçümleri için biyoelektrik impedans cihazı kullanılmıştır. İçme sularında ölçülmüş kobalt (Co), bakır (Cu), Demir (Fe), manganez (Mn) ve selenyum (Se) ve çinko $(\mathrm{Zn})$ değerleri kullanıldı.

Bulgular: İçme suyu Se mineral içeriğinin Batman'da yaşayan 55-70 yaş aralığındaki kadınlara ait vücut kütle indeks değerleri ile korelasyon gösterdiği tespit edilmiştir. Ayrıca, içme suyu Fe, Cu, Co, Zn, Mn ve Se seviyelerinin 55-70 yaş aralığındaki kadınlara ait abdominal obezite değerleri ile anlamlı düzeyde ilişkili olduğu görülmüştür.

Sonuç: $\mathrm{Fe}, \mathrm{Cu}, \mathrm{Co}, \mathrm{Zn}, \mathrm{Mn}$ ve özellikle Se içeriği yüksek olan içme suyunu tüketen 55-70 yaş arası kadınlarda obezite riskinin daha yüksek olabileceği öne sürülebilir.

Anahtar kelimeler: İçme suyu, Besinsel elementler, Yaşlılarda obezite, Vücut kütle indeksi, Abdominal yağlanma

\section{INTRODUCTION}

Appropriate nutrition of all metabolically active cells and tissues is essential for preserving a healthy human body. Micronutrients, including nutritional elements, vitamins and antioxidants play a vital role in continuously occurring regenerative processes, coping with consisting oxidative stress in body tissues and sustaining ample immunity against pathogens $[1,2]$.

An augmenting understanding of cellular targets and biochemical mechanisms of nutritional minerals has exacerbated the attentions of scientists to their share in obesity $[3,4]$. Potent nutritional elements, such as Se, except for their antioxidant role, have at the same time been involved in glucose regulation and insulin signaling pathways. The necessary nutritional element, selenium, has recently attracted a significant attention owing to its potential in maintenance of human health. Nutritional elements are essential nutrients needed by the body in trace amounts for regular process of body functions [5]. By causing obesity, nutritional elements, which are associated with carbohydrate and fat metabolism in an organism, may be related with the impairment of indirect homeostasis [6]. The extensity of overweight and obese individuals is increasing in all age groups, including the elderly group; and inadequate retrieval of nutritional elements has been stated to be in connection with obesity [7-10]. Recent studies have shown that some nutritional elements correlate with body compositions [11,12]. Imbalances between recommended amounts and mineral intakes have been seen in the elderly subjects. Nonetheless, evaluation of nutritional elements' status in the elderly is hard, even because infection and inflammation increase ferritin. Mineral bioavailability may alter because of ageing. For this reason, formulation of mineral suggestions is complex and individual recommendations are essential from time to time [13]. In previous studies, the risk of 
nutritional element imbalances was found to be higher in overweight children and adults than those of control group ones $[14,15,16]$. In some studies, body mass index was correlated with serum ferritin levels, and it has been reported that cellular zinc levels and serum copper levels are associated with obesity $[17,18]$.

In the body, thermal equilibrium hydroelectric and acid based balance is important for water [19]. Water consumption has heterogeneous impacts; for instance, energy intake, energy consumption, fat oxidation and body weight vary, while it prevents the development of metabolic diseases in terms of human health [20]. For this reason, water consumption is important in examination of the pathophysiology of obesity. Drinking water can be an important food source owing to some useful nutritional elements and nutritional element levels found in drinking water may be related to body composition in elderly subjects [21]. It has been found that nutritional elements are related to body composition, but there is no study mentioning this issue in women aged 55-70, and the correlation between drinking water nutritional elements and body composition has been surveyed. Therefore, in our study, it was aimed to examine the correlation between nutritional elements levels in drinking water and body composition of women at the age of 55-70.

\section{METHODS}

\section{Study Population}

The population of the study was made up of 80 subjects having come to the Diet Polyclinic of Batman Regional State Hospital between July 2015 and late December 2015. Before the study, we received ethics committee approval from ethics committee of BatmanUniversity (06.07.2015/2015/1-1). All of the participants were enlightened with elaborate information over the purpose of the research work; and informed about consent form was confirmed by every participant. All of the participants involved in the study were using tap water or water supplied from well. Subjects who consumed drinking water from bottled water or different water resources were let out of the research.

They were divided into three groups as overweight $(\mathrm{n}=27)$, obese $(\mathrm{n}=26)$, and control $(n=27)$. All subjects were female, aged $55-70$, living in Batman Province; however, there were no participants taking medication regularly during the research, they were not diagnosed to be suffering from any systemic diseases; for example, coronary heart disease, diabetes and cancer, either.

The subjects were sorted out as controls, overweight and obese, in line with BMIs of 18.5-24.9, 25.0-29.9, and $>30 \mathrm{~kg} / \mathrm{m} 2$, respectively. A stadiometer mounted on the wall was utilized to gauge each participant's height to the nearest $0.1 \mathrm{~cm}$. An electronic balance was employed to find out the weight of each subject. BMI was found as weight in kilograms divided by the square of the height in meters $(\mathrm{kg} / \mathrm{m} 2)$.

\section{Measurement of Body Composition}

In Batman Regional State Hospital Dietetic polyclinic, body composition measurements were performed with the help of a bioelectrical impedance analyser (BIA; Tanita BC 418 MA [22]. It is quite easy that Tanita BC $418 \mathrm{MA}$ body composition analyser may display body mass readings for the arm and leg separately. In this work, together with body weight, fat free mass, fat mass, body density, basal metabolic rate (BMR), activity calories, total activity calories and skeletal muscle mass, body composition parameters were measured with BIA [23]. 


\section{Sampling and Analytical Procedures}

Measured values of elements in drinking water from groundwater reservoir supplying water for Batman or wells were used. Every subject was paired with a source in compliance with her residence address and type of consumption so that it would be possible to search the connection between levels of drinking water elements and participant's body compositions. In harmony with international standards, it has been stated that water samples, taken for drinking water element analysis, were conserved in a portable fridge at $+4{ }^{\circ} \mathrm{C}$ [24], and $\mathrm{Fe}, \mathrm{Cu}, \mathrm{Co}, \mathrm{Zn}, \mathrm{Mn}$ and $\mathrm{Se}$ contents of samples were chemically analysed by means of $2 \mathrm{C}$ Full Suite (ACME Analytical Laboratories, Vancouver, CA) via inductively coupled plasma mass spectrometry [25].

\section{Statistical Analysis}

Statistical analyses were assessed by benefiting from SPSS package program 15.0 and Sigma Stat 3.5. The Kolmogorov-Smirnov test was utilized to find out if the data were convenient for normal distribution. One-way ANOVA test was employed to inquire into the differences between the groups, and Chi-square test was employed to assess the categorical variables.
Pearson and Spearman correlation tests were employed so as to study the connection between drinking water nutritional element levels and body composition of the elderly. Categorical variables were shown in numbers, while perpetual variables were stated as mean \pm standard deviation $(\mathrm{X} \pm \mathrm{SS}$ ) or median (25th75 th). Statistical significance level was found out as 0.05 .

\section{RESULTS}

The basic characteristics and bioelectrical impedance measurements of the study groups are shown in Table 1 . There is no statistically significant difference between age and height averages in the study groups, and in all groups, the mean age of the subjects participating in the study is approximately 60 .

Body weight and BMI values were found as $77.3 \pm 11.9$ and $84.3 \pm 10.37 ; 28.3 \pm 1.63$ and $33.2 \pm 2.05$, respectively in overweight and obese women. In the control group, these values were found as $60.9 \pm 9.0$ and $23.3 \pm 2.43$, respectively. FM, Fat\% and abdominal adiposity revealed to be substantially higher in the obese than overweight and control group $(\mathrm{p}<0.001$; Table 1$)$. 
Table 1: Baseline characteristics and BIA measurements of the participants

\begin{tabular}{|c|c|c|c|c|c|c|}
\hline \multirow[b]{2}{*}{ Parameters } & \multicolumn{2}{|c|}{ Study Groups } & \multirow{2}{*}{$\begin{array}{c}\text { Controls } \\
(n=27)\end{array}$} & \multicolumn{3}{|c|}{ Comparisons } \\
\hline & $\begin{array}{c}\text { Overweight } \\
(n=27)\end{array}$ & $\begin{array}{c}\text { Obese } \\
(n=26)\end{array}$ & & $\begin{array}{c}\text { Overweigh } \\
t \text {-Control }\end{array}$ & $\begin{array}{l}\text { Obesity } \\
\text {-Control }\end{array}$ & $\begin{array}{c}\text { Overweigh } \\
\text { t-Obese }\end{array}$ \\
\hline Age & $60.4 \pm 5.1$ & $60.8 \pm 6.3$ & $60.5 \pm 6.4$ & $\mathrm{p}=0.440$ & $\mathrm{p}=0.295$ & $\mathrm{p}=0.983$ \\
\hline Height & $164.6 \pm 9.8$ & $159.0 \pm 8.84$ & $161.2 \pm 7.9$ & $\mathrm{p}=0.845$ & $\mathrm{p}=0.894$ & $\mathrm{p}=0.448$ \\
\hline Body Weight & $77.3 \pm 11.9$ & $84.3 \pm 10.37$ & $60.9 \pm 9.0$ & $\mathrm{p}<0.001$ & $\mathrm{p}=0.125$ & $\mathrm{p}<0.001$ \\
\hline BMI & $28.3 \pm 1.63$ & $33.2 \pm 2.05$ & $23.3 \pm 2.43$ & $\mathrm{p}<0.001$ & $\mathrm{p}<0.001$ & $\mathrm{p}<0.001$ \\
\hline FFM & $51.4 \pm 8.06$ & $51.2 \pm 9.0$ & $45.0 \pm 6.71$ & $\mathrm{p}=0.017$ & $\mathrm{p}=0.042$ & $\mathrm{p}=0.496$ \\
\hline SMM & $48.9 \pm 8.0$ & $48.8 \pm 8.7$ & $42.9 \pm 6.47$ & $\mathrm{p}=0.021$ & $\mathrm{p}=0.053$ & $\mathrm{p}=0.492$ \\
\hline BM & $2.54 \pm 0.32$ & $2.46 \pm 0.35$ & $2.05 \pm 0.26$ & $\mathrm{p}<0.001$ & $\mathrm{p}<0.001$ & $\mathrm{p}=0.647$ \\
\hline FM & $25.8 \pm 4.69$ & $33.1 \pm 6.57$ & $15.9 \pm 6.35$ & $\mathrm{p}=0.003$ & $\mathrm{P}<0.001$ & $P<0.001$ \\
\hline Fat $\%$ & $33.3 \pm 3.24$ & $39.3 \pm 6.23$ & $25.3 \pm 8.98$ & $\mathrm{p}=0.090$ & $\mathrm{p}<0.001$ & $\mathrm{p}<0.001$ \\
\hline Mineral Mass (kg) & $3.19 \pm 0.52$ & $3.17 \pm 0.55$ & $2.79 \pm 0.41$ & $\mathrm{p}=0.017$ & $\mathrm{p}=0.044$ & $\mathrm{p}=0.487$ \\
\hline Protein Mass (kg) & $10.6 \pm 1.71$ & $10.5 \pm 0.55$ & $9.25 \pm 1.36$ & $\mathrm{P}=0.016$ & $\mathrm{p}=0.041$ & $\mathrm{P}=0.487$ \\
\hline Abdominal adiposity & $10.0 \pm 3.39$ & $12.8 \pm 2.59$ & $8.25 \pm 1.13$ & $\mathrm{P}=0.545$ & $\mathrm{P}<0.001$ & $\mathrm{P}=0.028$ \\
\hline Body density & $1.02 \pm 0.07$ & $1.007 \pm 0.13$ & $1.03 \pm 0.02$ & $\mathrm{P}=0.079$ & $\mathrm{p}<0.001$ & $\mathrm{p}<0.001$ \\
\hline BMR & $19.7 \pm 0.79$ & $18.3 \pm 1.52$ & $21.8 \pm 2.13$ & $P=0.064$ & $\mathrm{p}<0.001$ & $\mathrm{P}=0.001$ \\
\hline Activity Calorie & $166.0(156.2-179.3)$ & $146.5(146.5-162.9)$ & $192.0(166.0-227.6)$ & $\mathrm{P}=0.108$ & $\mathrm{P}<0.001$ & $\mathrm{P}=0.010$ \\
\hline Total Activity Calorie & $1694.2 \pm 243.5$ & $1707.8 \pm 262.9$ & $1510.7 \pm 188.6$ & $\mathrm{P}=0.018$ & $\mathrm{P}=0.023$ & $\mathrm{P}=0.649$ \\
\hline Body Water Weight & $37.6 \pm 6.13$ & $37.5 \pm 6.60$ & $32.9 \pm 4.92$ & $\mathrm{P}=0.018$ & $\mathrm{P}=0.042$ & $P=0.499$ \\
\hline Body Fluid Ratio & $48.7 \pm 2.3$ & $44.4 \pm 4.57$ & $54.6 \pm 6.5$ & $\mathrm{P}=0.086$ & $\mathrm{p}<0.001$ & $\mathrm{p}<0.001$ \\
\hline
\end{tabular}

Table 2 demonstrates the relationship between body composition of women and $\mathrm{Fe}, \mathrm{Cu}, \mathrm{Co}, \mathrm{Zn}$ and $\mathrm{Mn}$ levels in drinking water. The level of $\mathrm{Fe}$ in drinking water showed a statistically positive correlation with height, FFM, SSM, BM, mineral mass, protein mass, body density, BMR, activity calorie, total activity calorie, body water weight and body fluid ratio values of women aged 55-70. Copper levels of drinking water was positively correlated with FFM, SMM, mineral mass, protein mass, abdominal adiposity, BMR, total activity calorie and body water weight of women (Table 2). Other correlation values are displayed in Table 2 .

Table 2: Correlations between body composition of women and nutritional element levels in drinking waters

\begin{tabular}{|c|c|c|c|c|c|}
\hline Parameters & $\mathrm{Fe}$ & $\mathrm{Cu}$ & Co & Zn & Mn \\
\hline Height & $0.298^{*}$ & 0.257 & 0.112 & 0.131 & 0.115 \\
\hline Body Weight & 0.146 & 0.247 & 0.218 & 0.216 & 0.218 \\
\hline BMI & -0.088 & 0.060 & 0.146 & 0.127 & 0.144 \\
\hline FFM & $0.427^{* *}$ & $0.293^{*}$ & 0.260 & $0.279^{*}$ & 0.262 \\
\hline SMM & $0.432^{* *}$ & $0.295^{*}$ & $0.264^{*}$ & $0.283^{*}$ & $0.266^{*}$ \\
\hline BM & $0.281^{*}$ & 0.215 & 0.154 & 0.169 & 0.155 \\
\hline FM & -0.232 & 0.051 & 0.042 & 0.019 & 0.041 \\
\hline Fat $\%$ & -0.378 & -0.083 & -0.060 & -0.086 & -0.062 \\
\hline Mineral Mass (kg) & $0.426^{* *}$ & $0.293^{*}$ & 0.258 & $0.277^{*}$ & 0.260 \\
\hline Protein Mass (kg) & $0.430^{* *}$ & $0.291 *$ & $0.264^{*}$ & $0.284^{*}$ & $0.266^{*}$ \\
\hline Abdominal adiposity & 0.130 & $0.283^{*}$ & $0.384^{* *}$ & $0.372^{* *}$ & $0.383^{* *}$ \\
\hline Body density & $0.382^{* *}$ & 0.081 & 0.054 & 0.080 & 0.056 \\
\hline BMR & $0.404^{* *}$ & $0.292^{*}$ & 0.262 & $0.278^{*}$ & $0.263^{*}$ \\
\hline Activity Calorie & $0.439 * *$ & 0.132 & 0.102 & 0.126 & 0.104 \\
\hline Total Activity Calorie & $0.427^{* *}$ & $0.293^{*}$ & 0.259 & $0.278^{*}$ & 0.261 \\
\hline Body Water Weight & $0.426^{* *}$ & $0.293^{*}$ & 0.259 & $0.278^{*}$ & 0.261 \\
\hline Body Fluid Ratio & $0.377^{* *}$ & 0.084 & 0.058 & 0.084 & 0.060 \\
\hline
\end{tabular}


Table 3 shows the relationship between body composition of women and $\mathrm{Mo}, \mathrm{Se}, \mathrm{Cr}$ and $\mathrm{Br}$ levels in drinking water. Selenium was positively correlated with BMI, FM, F\% and abdominal adiposity while negatively correlated with body density, activity calorie and body water ratio of women (Table 3). Other correlation values are shown in table 3.

Table 3: Correlations between body composition of women and nutritional element levels in drinking waters

\begin{tabular}{lcccc}
\hline \multicolumn{1}{c}{ Parameters } & Mo & Se & Cr & Br \\
\hline Height & -0.198 & -0.179 & 0.213 & -0.077 \\
Body Weight & -0.110 & 0.403 & 0.249 & 0.135 \\
BMI & 0.043 & $\mathbf{0 . 6 4 9 * *}$ & 0.102 & 0.247 \\
FFM & -0.153 & -0.018 & 0.243 & 0.041 \\
SMM & -0.157 & -0.020 & 0.243 & 0.040 \\
BM & -0.037 & 0.032 & 0.215 & 0.073 \\
FM & -0.001 & $\mathbf{0 . 5 9 2 * *}$ & 0.104 & 0.150 \\
Fat \% & 0.047 & $\mathbf{0 . 5 4 4 *}$ & 0.024 & 0.173 \\
Mineral Mass (kg) & -0.152 & -0.018 & 0.241 & 0.040 \\
Protein Mass (kg) & -0.154 & -0.021 & 0.245 & 0.044 \\
Abdominal adiposity & -0.189 & $\mathbf{0 . 4 8 0 * *}$ & 0.232 & 0.062 \\
Body density & -0.038 & $-\mathbf{0 . 5 4 0}$ & -0.033 & -0.178 \\
BMR & -0.149 & 0.057 & 0.251 & 0.060 \\
Activity Calorie & -0.128 & $\mathbf{- 0 . 4 0 9 * *}$ & 0.004 & -0.200 \\
Total Activity Calorie & -0.152 & -0.017 & 0.242 & 0.039 \\
Body Water Weight & -0.152 & -0.017 & 0.242 & 0.041 \\
Body Water Ratio & -0.046 & $\mathbf{- 0 . 5 4 4 * *}$ & -0.026 & -0.176 \\
\hline *P<0.05, ** P<0.01; BMI: Body mass index, FFM: Fat free mass, \\
SMM: Skeletal muscle mass, BM: Bone mass, FM: Fatt mass, Fat ratio, \\
BMR: Basal metabolic rate. & & &
\end{tabular}

\section{DISCUSSION}

In our research, we ascertained that Se mineral content in drinking water correlated with the BMI of women aged 55-70 while it was negatively correlated with body density, activity calorie and body water ratio of them.

Selenium has an insulin-mimetic action via activation of protein kinases; consequently, its deficiency may be liable for degenerated insulin susceptibility [26, 27]. Selenium has also other functions such as biotransformation, detoxification and the immune response.
Primary importance of $\mathrm{Se}$ is that it is a nutritional element needed by glutathione peroxidase which has a significant role in the organism protection against oxidative stress. It is known also that oxidative stress is related with pathological processes; for example, obesity, diabetes, cardiovascular disease, and atherogenic processes. It is also notified that oxidative stress is connected with irregular generation of adipokines, contributing to the progressing of the metabolic syndrome and, in turn, obesity might trigger systemic oxidative stress [28]. The oxidative damage is greater in persons with obesity and directly correlates with BMI and the body fat percentage, on the other hand, antioxidant defence markers are lower in respect to the quantity of body fat [2931]. High-Se diets might induce the freeing of glucagon, promoting hyperglycaemia, or could cause overexpression of glutathione peroxidase-1 and other antioxidant selenoproteins, leading to insulin resistance and obesity [32]. Adverse health impacts of Se are known and might occur owing to supranutritional Se intake even below the levels necessary for intoxication [33]. It has been found that high Se levels give rise to increased adiposity and may also increase the risk of diseases; for instance, hypertension, diabetes, and dyslipidaemia [34].

In present study, we found that Se content in drinking water correlated with the BMI, body density, activity calorie and body water ratio of women aged 55-70. However, due to restricted information existing about the influence of Se present in drinking water on weight loss or gain, further investigations is needed for finding out the connection between obesity and Se levels in drinking water.

On the other hand, BMI, which is most commonly used in determining nutritional status in young and middle-aged individuals, cannot specify the degree of obesity due to body composition changes in the elderly. Thus, the connection between BMI and illness risk is 
very poor in old individuals [35]. On the other hand, it was suggested that the measure of adiposity is the best predictor of the effects of obesity on health results in the old [36]. Therefore, probably, most important findings of our investigation are that the demonstration of the $\mathrm{Cu}, \mathrm{Co}, \mathrm{Zn}, \mathrm{Mn}$ and Se levels of drinking water correlates with the abdominal adiposity of women aged 55-70.

One of the most important elements necessary for generation of red blood cells and for different key cuproenzymes is copper. In general malnutrition and long term diarrhoea, it has been notified that there are low serum copper levels. In spite of malnutrition, it has been demonstrated that high serum copper levels in obese children could be due to their good appetite [37]. But no studies have been come across to have examined the relationship between drinking water copper levels and fat tissue formation in women aged 55-70. On the other hand, former researches demonstrated that cobalt chloride treatment may repair highfat diet-induced hypertrophic adipocytes to their normal size [38]. Blood glucose levels and visceral fat content reduce, while adiponectin level increases with the help of cobalt protoporphyrin supplementation in obese/diabetic animal models [39]. As restricted data are present on the influence of Co in drinking water on weight loss or attainment, additional investigations ought to search for determining the connection between obesity and Co levels of drinking water.

In nutritional element metabolism, zinc has significant impacts on thermoregulation of obese persons. Zn levels in obese patients were substantively lower than those in control group, yet the BMI values were meaningfully higher. At the last phase of severe hypocaloric diet, serum $\mathrm{Zn}$ and BMI levels came back to normal levels [40]. In researches conducted before, it has been also determined that $\mathrm{Mn}$ acts as an accelerator in fat breakdown and cholesterol. It is necessarily essential for the metabolism of vitamin B1, C and E, and for activation of several enzymes that are crucial for appropriate digestion and making use of foods [41]. In this survey, Mn levels in water were positively correlated with SMM, protein mass, abdominal adiposity and BMR values of women. Suitable Mn levels are necessary for progress of the normal insulin synthesis and secretion [42].

In present paper, we also found that Fe content in drinking water positively correlated with body compositions especially FFM, SMM, BM, protein mass, mineral mass and body density. These findings indicate that $\mathrm{Fe}$ levels in drinking water positively correlated with almost all parameters rather than the related formation of fat tissues such as BMI, FM and F\% of women aged 55-70. More reduced concentrations of serum iron with increasing BMI were seen some ten years ago and certified in ensuing researches. In grownups, a number of various analyses indicated lower serum iron concentrations with higher BMI, especially in women. Nevertheless, outcomes seem to be far more complex in grownups when compared with adolescents. For this reason, only one study put forward lower serum iron concentrations in overweight women, yet with no distinction in men [43].

Similar to $\mathrm{Se}, \mathrm{Cu}, \mathrm{Zn}$ and $\mathrm{Mn}$ elements, as restricted information about the influence of $\mathrm{Fe}$ in drinking water on weight loss or gain is available, full biological significances between Fe contents of drinking water and body compositions are far from being completely understood. Nevertheless, the observed association of abdominal adiposity of women aged 55-70 with Fe levels of drinking water found out in this study is intriguing; and it could be speculated that Fe content of drinking water might have some significant regulatory impacts on body weight.

As a result, the findings of the existing investigation may offer that the obesity risk may be higher in women who are aged between 
55-70 and consume drinking water having a high $\mathrm{Fe}, \mathrm{Cu}, \mathrm{Co}, \mathrm{Zn}, \mathrm{Mn}$ especially Se content. However, as the number of studies having analysed the biochemical effects of nutritional minerals in drinking water on body composition of women aged 55-70 is insufficient, the full biological significances of these correlations are far from being completely understood; therefore, they certainly require further investigations.

Declaration of Conflicting Interests: The authors declare that they have no conflict of interest.

Financial Disclosure: No financial support was received.

\section{REFERENCES}

1. Rai KN, Kumari NS, Gowda KmD, et al. The Evaluation of Micronutrients and Oxidative Stress and their Relationship with the Lipid Profile in Healthy adults. J Clin Diagn Res 2013;7:1314-8.

2. Demir AD, Erenberk U, Özgen İT, et al. Total antioxidant and oxidant status in obese children without insulin resistance. Dicle Med J 2014;41:257-61

3. Guerrero RF, Rascón RA, Rodríguez MM, et al. Hypomagnesaemia and risk for metabolic glucose disorders: a 10-year follow-up study. Eur J Clin Investig 2008;38:389-96.

4. Chinyere NA, Opera UA, Henrietta EM, et al. Serum and urine levels of chromium and magnesium in type 2 diabetics in Calabar, Nigeria. Mal J Nutr 2005;11:13342.

5. Matsumura M, Nakashima A, Tofuku Y. "Electrolyte disorders following massive insulin overdose in a patient with type 2 diabetes. Internal Medicine 2000;39:55-7.

6. Błoniarz J, Zareba S. Selected microelements (Cr, Zn, $\mathrm{Cu}, \mathrm{Mn}, \mathrm{Fe}, \mathrm{Ni}$ ) in slimming preparations. Rocz Panstw Zakl Hig 2007;58:165-70.

7. Mathus-Vliegen EM, Basdevant A, Finer $\mathrm{N}$, et al. Prevalence, pathophysiology, health consequences and treatment options of obesity in the elderly: a guideline. Obesity Facts 2012;5:460-83.

8. Han TS, Tajar A, Lean ME. Obesity and weight management in the elderly. Br Med Bull 2011;97:16996.

9. Yerlikaya H, Aysun T. Obezite ve eser elementler. Endokrinolojide Diyalog 2012;9:64-70.
10. Tascilar ME, Ozgen IT, Abaci A, et al. Trace elements in obese Turkish children. Biol Trace Elem Res 2011;143:188-95.

11. Barceloux DG. Nickel. J Toxicol Clin Toxicol 1999;37:239-58.

12. Coogan TP, Latta DM, Snow ET, et al. Toxicity and carcinogencity of nickel compounds. Crit Rev Toxicol 1989;19:341-84.

13. Vaquero MP. Magnesium and trace elements in the elderly: intake, status and recommendations. J Nutr Health Aging 2002;6:147-53.

14. Whanger PD. Effects of dietary nickel on enzyme activities and mineral contents in rats. Toxicol Appl Pharmacol 1973;25:323-31.

15. Arpasova H, Capcarova M, Kalafova A, et al. Nickel induced alteration of hen body weight, egg production and egg quality after an experimental peroral administration. J Environ Sci Health B 2007;42:913-8.

16. Azab SF, Saleh SH, Elsaeed WF, et al. Serum trace elements in obese Egyptian children: a case-control study. Ital J Pediatr. 2014;40:20.

17. Faulk C, Barks A, Liu K, et al. Early-life lead exposure results in dose- and sex-specific effects on weight and epigenetic gene regulation in weanling mice. Epigenomics 2013;5:487-500.

18. Kim R, Hu H, Rotnitzky A, et al. longitudinal study of chronic lead exposure and physical growth in Boston children. Environ Health Perspect 1995;103:952-7.

19. Rubiano F, Nuñez C, HeymsfieldSD. A comparison of body composition techniques. Ann N Y Acad Sci 2000;904:335-8.

20. Malavolti M, Mussi C, Poli M, et al. Cross-calibration of eight-polar bioelectrical impedance analysis versus dual-energy X-ray absorptiometry for the assessment of total and appendicular body composition in healthy subjects aged 21-82 years. Ann Hum Biol 2003;30:380-91.

21. WHO. Guidelines for drinking-water quality (4th ed.). Geneva: World Health Organization 2011.

22. Völgyi E, Tylavsky FA, Lyytikäinen A, et al. Assessing body composition with DXA and bioimpedance: effects of obesity, physical activity, and age. Obesity 2008;16:700-5.

23. Ryo M, Maeda K, Onda T, et al. A new simple method for the measurement of visceral fat accumulation by bioelectrical impedance. Diabetes Care 2005;28:451-3.

24. APHA, AWWA, WEF. Standard Methods for examination of water and wastewater. 22nd ed. Washington: American Public Health Association 2012;1360.

25. Nalbantçılar MT, Pınarkara SY. Batman Şehir Merkezi Yeraltı Suyu Kirliliği. Batman Üniversitesi Bilimsel Araştırma Projesi Sonuç Raporu, 2014. 
26. Ahn B-I, Kim MJ, Koo HS, et al. Serum zinc concentration is inversely associated with insulin resistance but not related with metabolic syndrome in nondiabetic Korean adults. Biol Trace Elem Res 2014;160:169-75.

27. Gao H, Hagg S, Sjogren P, et al. Serum selenium in relation to measures of glucose metabolism and incidence of type 2 diabetes in an older Swedish population. Diabet Med 2014;31:787-93.

28. Esposito K, Ciotola M, Giugliano D. Oxidative stress in the Metabolic Syndrome. J Endocrinol Invest 2006;29:791-5.

29. Pihl E, Zilmer K, Kullisaar T, et al. Atherogenic inflammatory and oxidative stress markers in relation to overweight values in male former athletes. Int J Obesity 2006;30:141-6.

30. Chrysohoou C, Panagiotakos DB, Pitsavos C, et al. The implication of obesity on total antioxidant capacity apparently healthy men and women: The ATTICA study. Nutr Metab Cardiovasc Dis 2007;17:590-7.

31. Hartwich J, Goralska J, Siedlecka D, et al. Effect of supplementation with vitamin $\mathrm{E}$ and $\mathrm{C}$ on plasma hsCPR level and cobalt-albumin binding score as markers of plasma oxidative stress in obesity. Genes Nutr 2007;2:151-4.

32. Stranges S, Sieri S, Vinceti $M$, et al. A prospective study of dietary selenium intake and risk of type 2 diabetes. BMC Public Health. 2010;10:564.

33. Steinbrenner H, Speckmann B, Pinto A, et al. High selenium intake and increased diabetes risk: experimental evidence for interplay between selenium and carbohydrate metabolism. J Clin Biochem Nutr 2011;48:40-5.

34. Laclaustra M, Navas-Acien A, Stranges S, et al. Serum selenium concentrations and hypertension in the US population. Circ Cardi-ovasc Qual Outcomes 2009;2:369-76.
35. Çevik A. Evde Sağlık Hizmeti Alan Yaşlı Hastalarda Beslenme Durumunun Değerlendirilmesi ve Beslenme Durumunun Laboratuar Parametreleri Üzerine Olan Etkisinin İrdelenmesi. Konuralp Tıp Dergisi 2014;3:317.

36. Chau D, Cho LM, Jani $\mathrm{P}$, et al. Individualizing recommendations for weight management in the elderly. Curr Opin Clin Nutr Metab Care 2008;11:2731.

37. Yakinci C, Paç A, Küçükbay FZ, et al. Serum zinc, copper, and magnesium levels in obese children. Acta Paediatr Jpn 1997;39:339-41.

38. Nicolai A, Li M, Kim DH, et al. Heme oxygenase-1 induction remodels adipose tissue and improves insulin sensitivity in obesity-induced diabetic rats. Hypertension 2009;53:508-15.

39. Kawakami T, Hanao N, Nishiyama K, et al. Differential effects of cobalt and mercury on lipid metabolism in the white adipose tissue of high-fat diet-induced obesity mice. Toxicol Appl Pharmacol 2012;258:32-42.

40. Di Martino G, Matera MG, De Martino B, et al. Relationship between zinc and obesity. J Med 1993;24:177-83.

41. Rashed MN. The role of trace elements on hepatitis virus infections: A review. J Trace Elem Med Biol 2011;25:181-7.

42. Korc M. Manganese action on pancreatic protein synthesis in normal and diabetic rats. The American Journal of Physiology. 1983;245:628-34.

43. Micozzi MS, Albanes D, Stevens RG. Relation of body size and composition to clinical biochemical and hematologic indices in us men and women. Am J Clin Nutr 1989;50:1276-81. 
Dicle Tıp Dergisi / Dicle Medical Journal

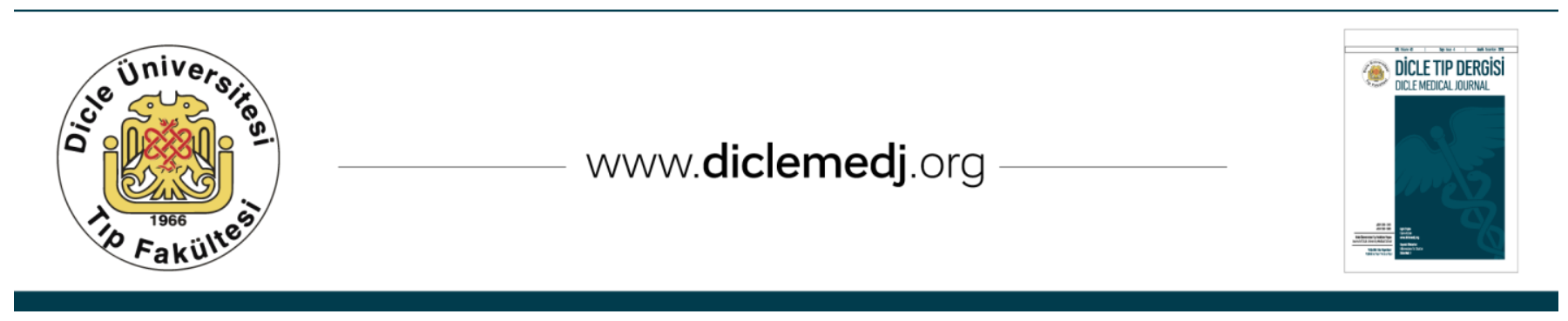

